\title{
Artes y ciencias en la formación de Fray Luis de León y uso que hace de ellas
}

\section{Saturnino Álvarez Turienzo}

Arbor CLXXIII, 683-684 (Noviembre-Diciembre 2002), 481-512 pp.

\section{La generación de Fray Luis}

Fray Luis de León nace en 1527, el mismo año que Felipe II. Figuras, pues, rigurosamente coetáneas. De genios en buena medida contrarios, alcanzarán su madurez en la mitad segunda del siglo XVI. Los dos mueren en su última década, con siete años de diferencia; fray Luis en 1591, el Rey en 1598. Autores de nota han señalado ese tiempo con el mote de «siglo de Felipe II», lo que no produce extrañeza. También hay quien ha preferido llamarle «siglo de fray Luis de León», lo que acaso sólo se acepte si se le mira desde una especial óptica. Como aquí voy a ocuparme del maestro agustino voy a apropiarme de esa especial óptica, que atiende a aquello en que fray Luis ocupó su vida, o sea el cultivo de artes y ciencias: señaladamente la ciencia teológica. En razón de ello quiero empezar dejando marcado el año de su nacimiento.

Esa cifra numeral de 1527 pienso que puede tomarse como fecha ordinal a la que referir el arranque de definidos movimientos de cultura modificándose con ellos el clima espiritual de la época. Los hombres que encarnan y conducen esos movimientos corresponden a una sociedad en expansión, sociedad abierta, ávida de nuevas experiencias y conocimientos. Con el discurrir de las cosas derivará la centuria hacia una sociedad cerrada. Y si hubiera que fijar al caso una fecha de inflexión, esta sería la de 1559, señalada por la represión oficial de los brotes protestantes y la restricción impuesta por Felipe II a la 
libre asistencia de estudiosos a centros de más allá del reino. Esa fecha de 1559 marcaría el tipo de pensamiento de nuevas generaciones cuyos pasos acabarían en la «tibetanización» por la que se ha definido el periodo siguiente ${ }^{1}$.

Volviendo a la fecha de nacimiento de fray Luis, me aventuraría a hablar de una generación del «27», dentro de aquel siglo; y etiquetarla como la de fray Luis de León.

Nombraré otros dos personajes, que nacen el mismo año y que cuentan en el entorno inmediato del maestro salmantino, amistoso con él el uno, enemistoso el otro. Me refiero a Benito Arias Montano y Bartolomé de Medina. Los dos nacen también en la indicada fecha de 1527.

Bartolomé de Medina figura en la sucesión de teólogos dominicos, que pasa por Melchor Cano, Domingo Soto, hasta Báñez (nacido este último en 1528), y que tiene su comienzo en la enseñanza de Francisco de Vitoria, catedrático de prima en la universidad desde 1526. Esa línea de maestros decide la orientación de los estudios en la Facultad. Implantan en ella la escolástica, teniendo por guía el magisterio de santo Tomás de Aquino, que de Vitoria a Báñez, tenderá a imponerse en las escuelas como doctrina y método excluyente de otras «vías».

Arias Montano, por su parte, formado en la universidad de Alcalá, comulga con el espíritu que domina en ese centro. Allí oye las lecciones del profesor de Escritura Cipriano de la Huerga que tomó el hábito del Císter en 1527. Esa cátedra había sido creada en 1532, regentándola el agustino Dionisio Vázquez. Fray Luis de León seguirá asimismo (curso 1556-1557) al maestro cisterciense sucesor de Vázquez. Lo que atraía de esa enseñanza, tanto a Arias Montano como a fray Luis, era su apertura de espíritu y el carácter positivo, bíblicamente orientado, de su teología ${ }^{2}$.

Añadiré dos hechos en los que se confirma la modificación del clima espiritual que se produce en torno a la fecha indicada.

El primero de ellos es la conferencia de doctos reunidos en Valladolid a efectos de examinar la ortodoxia de la obra erasmiana. Es también en 1527 cuando tiene lugar. La autoridad de Erasmo había alcanzado por entonces en España un ascendiente inusual. La traducción de su escrito más difundido, Enquiridion del caballero cristiano, fue editada en 1526.

Favorecían al holandés importantes personalidades del momento. Partidarios suyos, por lo común, eran los maestros de la academia alcalaína, contra lo que se observaba en la de Salamanca. Entre aquellas personalidades figuraban Alonso de Fonseca, arzobispo de Toledo, y 
hasta el inquisidor general Alfonso Manrique, arzobispo de Sevilla. Fue este último quien promovió la conferencia mencionada. En París la Sorbona condenó (1531) ciertas proposiciones que tocaban a la ortodoxia de Erasmo. El inquisidor Manrique se había pronunciado contra los ataques a la doctrina del humanista, pero sus émulos harán llegar a él un listado de puntos, extraídos de sus obras, calificados como heréticos. Fue lo que motivó la convocatoria de teólogos para examinar el caso. La conferencia de Valladolid se disolvió sin concluir sus trabajos. Erasmo no fue condenado, pero quedó sembrada la sospecha en torno a él. La condena oficial saldría del Concilio de Trento en 1552. En 1534 advertía ya Vives a Erasmo sobre lo difíciles y peligrosos tiempos que corrían.

De otra parte, en 1527 publica Francisco de Osuna el Tercer abecedario. La obra, para Melquíades Andrés, cierra un periodo y abre otro. Osuna se inserta en la corriente de los espirituales franciscanos. Se marca en ella un cambio, en el sentido de dar el paso desde una religiosidad exterior de cumplimiento a una espiritualidad interiorizada. La citada obra es para M. Andrés «la primera codificación de la mística de recogimiento» ${ }^{3}$. Traigo aquí esa obra por la fecha de publicación y por el revulsivo que su lectura habría de provocar en santa Teresa de Jesús. Esa lectura puede enlazarse con la que anteriormente había hecho de las Confesiones de san Agustín. Sumados sus efectos deciden la que vendrá a ser su personal experiencia mística, la de una nueva vía de oracion y comunicación con Dios. Generalizando el fenómeno vendríamos a dar en lo que algún autor ha descrito como «cambio de rumbo de la espiritualidad española a mediados del siglo XVI» ${ }^{4}$.

A los puntos indicados podrían añadirse otros. En ellos vendría a mostrarse el clima nuevo al que se abren las gentes de letras en nuestro siglo XVI a partir del tercer decenio. He tomado en cuenta la situación por el lado que da hacia el pensar y el vivir religiosos. Puesto que lo que entra directamente en mi interés es el pensamiento y la vida de fray Luis de León, llevaré el desarrollo subsiguiente al campo en que se movió su actividad profesional, es decir al de la teología. Puede considerarse inscrita en él su obra poética. No se excluye el papel que en esa profesión de teólogo tiene la mística. Tampoco al peso que, dentro de su teología, vendrán a tener las ciencias (entiendo las no específicamente religiosas) cultivadas en su tiempo.

Incluyo a fray Luis dentro de la corriente que define la modificación de mentalidad que va a afectar a los hombres de la generación a la que pertenece. Para situarle dentro de ella voy a empezar por extraer dos enseñanzas de lo expuesto. 
La primera afectaría a la modificación de métodos formativos e informativos, o sea de aprendizaje y de enseñanza. Esa modificación alcanza incluso al currículo escolástico, aunque ahí se haga menos visible. Es en cambio notoria en los tipos de saber que para el tiempo se presentan como innovadores. Novatores son, por supuesto, los humanistas, pero también los maestros universitarios que en los siglos XIV y XV (nominalistas) reorientan las disciplinas según los criterios de la via modernorum. Ello afectará hondamente a la teología. Dentro de los estudios profanos esa nueva inspiración modificará la concepción y desarrollo de la lógica. Sobre todo, y por lo que ello va a significar para el auge y configuración de la ciencia moderna, sentará las bases y dará la orientación para el modo de entender la física. Dichos nominales fueron menos sensibles para los problemas éticos, o se enfrentaron a ellos en términos más dubitativos. Es el campo, sin embargo, al que darán preferencia los humanistas.

Rasgo común a unos y otros, lo que define ya al método, fue el de su actitud escéptica respecto a la tradición escolástica en cuanto saber especulativo sustentado en inidentificables nociones metafísicas. A partir de ahí, lo que de positivo tenía ese método se bifurca en doble dirección, según que lo sometido a estudio sea el libro de la naturaleza o los libros transmisores de la cultura. Son los campos que se reparten entre los físicos, estudiosos de los realia y los humanistas, eruditos de los sermocinalia. La dualidad entre esos dos ámbitos era clara, aunque no se viviera como si se tratase de territorios incomunicados, al menos por el tiempo a que ahora atendemos. Lo que sí termina apareciendo, a su vez, como claro es que había dos métodos que permitían moverse con seguridad dentro de las respectivas fronteras. Uno de ellos quedaba codificado en las matemáticas. El otro en la gramática.

Que las matemáticas estuvieran llamadas a entenderse como la clave para descifrar los secretos del universo no quiere decir que esto ocurriese de pronto y como por un salto. Fue el resultado de un proceso que llena los siglos modernos. Entre tanto los hombres del Renacimiento fueron especialmente crédulos. Creían en brujas y se sentían rodeados de potencias mágicas. Estudios como los de la astrología o la alquimia tenían para ellos la autoridad de ciencias. El cosmos físico mismo era concebido como un ser animado y poblado de virtudes ocultas.

Ahora pasaré a la otra enseñanza que cabe extraer de los hechos anotados anteriormente y referidos a la fecha generacional de 1527 . Se trata en este caso de indicar las líneas en que pueden agruparse los intereses culturales del momento. Estarían representados en las posiciones siguientes ${ }^{5}$. 
1) La escolástica, asociada aquí al nombre de Bartolomé de Medina. Es la que encontramos sancionada en la docencia oficial de las Escuelas.

2) La filológico-gramatical. Es la que representa en forma eminente el nombre de Arias Montano.

3) La filológico-literaria, aplicable a Erasmo y la corriente de la philosophia Christi.

4) La espiritual-mística, que relacionábamos con la publicación del Tercer abecedario de Osuna.

Puede ser ilustrador adelantar, como observación de paso, que fray Luis de León estuvo interesado en los estudios o sabidurías de las cuatro. Enseñó escolástica los más de los años que duró su docencia. Los estudios de que gustaba, sin embargo, no eran los que se cursaban en las escuelas, sino los cultivados por los humanistas, en los que, durante sus años de formación, puso particular empeño. Una obra como De los nombres de Cristo testimonia su inclinación hacia la espiritualidad mística, inclinación que vemos sellada al notar que fue la que le atrajo en los años finales de su vida al ocuparse de la edición de la obra teresiana.

\section{Su perfil de sabio}

Se ha considerado su figura como la más representativa del Renacimiento hispano, típica muestra del ideal de homo universalis. Universal fue su curiosidad de saber. En su obra encontramos la prueba de haber poseído las destrezas más variadas. Entendió que todas ellas eran útiles al teólogo. A ese fin las puso en ejercicio él mismo. A veces se hace con la poesía un aparte dentro de su obra. Cierto que el propio fray Luis califica a sus poemas de «obrecillas», a las que dice haberse aplicado "por inclinación de su estrella», distinguiéndolas de lo que se hace "por juicio o voluntad». Pero le convence no tenerlas por un aparte de la teología el hecho de «haber usado Dios de ella [de la poesía] en muchas partes de sus sagrados Libros».

Por otra parte sabemos de la afinidad que, entre Teología y poesía, encontraba cierta línea de pensamiento de la época, a la que no era extraño fray Luis. Me refiero a la de los platónicos filiables a M. Ficino ${ }^{6}$.

En todo caso, el homo universalis que en él se nos muestra encuentra sus límites en haber sido, ante todo, un hombre de libros. Lo fue por 
formación y por dedicación, «por juicio y voluntad». Brilló como acucioso escudriñador de textos y como intérprete de mensajes. Fue, en este sentido, un hombre de letras. Como tal se aplicó a leer incluso el libro de la naturaleza. Sintió ésta con hondura y supo expresar ese sentimiento con eficacia literaria. No puede decirse, en cambio, que participara en su escrutinio metódico. A este respecto no fue un hombre de ciencia. Su curiosidad se extendía a estar al corriente de la que ofrecía su tiempo.

Puede que adivinara aquello a que iba a conducir un mal encaminado, por unilateral, cultivo de la ciencia que entonces echaba a andar: al «desencanto del mundo». El tono general de sus escritos no casa con esas andanzas. La imagen que él tenía de la naturaleza era la llena de encanto y misterio. Corría al unísono con la expresada en la filosofía más autorizada del momento: lo del platonismo trasladado a Italia por la emigración de los sabios bizantinos tras la caída de Constantinopla y renacido para los países occidentales en la escuela de Florencia.

El campo de estudios que absorbió a fray Luis fue el de una litterata Theologia. Su profesión fue la de humanista teólogo. En razón de teólogo no podía rechazar como mera «barbarie», aunque sería acusado de ello, la escolástica. Como teólogo humanista era llevado a conceder especial aprecio a la tradición de los santos. Y, en cuanto teólogo que sigue hasta el final la lógica de su profesión, elevará a canon rector de su disciplina a la Escritura. Por ello es por lo que le vemos, dentro del esquema de posiciones antes enumeradas, muy cerca de la significada por Arias Montano, o la de aquellos «hebraístas» universitarios con los que compartirá docencia en Salamanca (Gaspar Grajal y M. Martínez de Cantalapiedra) ${ }^{7}$. Más abierto que ellos, sin embargo, a la tradición de los Padres, al modo que se refleja en la posición de Erasmo. Y, menos puritano que el hebraísmo de unos y que el humanismo del otro, no se negará a contar con la ayuda que el teólogo puede recibir de la escolástica. Es, pues, el suyo un espíritu que busca integrar las aportaciones recibidas de distintas corrientes en una visión que fray Luis presenta como unitaria.

\section{Las letras sagradas, colmo y perfección de la Teología}

Unas líneas de la «Dedicatoria» a De los nombres de Cristo resumen cuanto a este respecto cabe decir. Viene hablando de lo que conviene que sepan los pastores y predicadores en punto a la justa proclamación 
de la palabra de Dios. Piensa que lo que ineludiblemente han de conocer es el Texto bíblico en el que esa palabra se contiene.

«Pero es en muchos esto tan al revés, que no sólo no saben estas letras, pero desprecian, o al menos muestran preciarse poco y no juzgar bien de los que las saben. Y con un pequeño gusto de ciertas cuestiones, contentos e hinchados, tienen título de maestros teólogos, y no tienen la Teología; de la cual, como se entiende, el principio son las cuestiones de la Escuela, y el crecimiento la doctrina que escriben los Santos; y el colmo y perfección y lo más alto de ella las Letras sagradas, a cuyo entendimiento todo lo de antes, como a fin necesario, se ordena» (NC, «Dedicatoria», p. 382) ${ }^{8}$.

Este pregnante párrafo no requiere comentario. Se descarga fray Luis en él de las acusaciones que se le hicieron ante la Inquisición, de mostrar desprecio por la escolástica, y de no tener estima de los Santos. Observamos cómo, por el contrario, en la declaración apuntada tienen cabida las diversas fuentes o lugares teológicos de la tradición. Pero los jerarquiza ordenando los más recientes a los más antiguos, y todos a la Escritura. De modo que los conocimientos derivados, sean los ofrecidos en sus interpretaciones exegéticas por los Padres, sean las Sumas de doctrina elaboradas por los escolásticos, en cuanto reclaman autonomía y proceden como si se sustentasen en sí mismos, derivan en quedarse con sólo el título de la teología buscada, sin tener su realidad. La teología que los magistri medievales cultivaron como nueva y científica desmerece ante la doctrina que tradicionalmente venían enseñando los sancti. Una y otra languidecen en caso de no tener arraigo en la sabiduría de la Escritura: océano de ciencia y de doctrina comunicada al hombre por Dios mismo. Nutriéndose de esa fuente, $\mathrm{y}$ «como si de ella fuesen nacidas», tendrán aquellas otras valor. Es el sentido en que las acoge fray Luis. Lo cual le permite defenderse con éxito contra quienes le censuran de menospreciar a maestros y a santos, o decir que para entender la Escritura bastaba sólo gramática ${ }^{9}$.

\section{Para entender la Escritura hay que saberlo todo}

Fray Luis responderá a acusaciones como las apuntadas que «para el entero entendimiento de la Escritura era menester saberlo todo, y principalmente tres cosas: la teología escolástica, lo que escribieron los santos, las lenguas griega y hebrea. Y aunque a mí me faltaba mucho de todo esto, pero que si en mi mano fuese el tenerlo, 
yo lo escogiera para el efecto sobredicho. Y los que se contentaban con menos eran hombres de mejor contento que yo. $\mathrm{Y}$ jamás traté ni en público ni en secreto del abismo de saber que Dios encerró en los libros de la Santa Escritura que no dijese que pedía en el que trataba de entenderla, que supiese todas las ciencias, y las historias, y las artes mecánicas, cuanto más la teología escolástica, que es la verdadera introducción a ella. Y a lo que dice que basta sola gramática para declarar la Escritura, como yo y otras personas la declaramos, yo nunca he profesado declararla, porque siempre he leído escolástica... Pero véanse mis lecturas y los lugares en ellas, adonde declaro pasos de Escritura que se ofrecen, y juzguen los hombres doctos y desapasionados si los declaro como gramático o como teólogo» ${ }^{10}$.

He aquí en cambio otro pasaje en el que enjuicia el saber teológico de los que se contentan con menos que él, en concreto aquellos a quienes basta la escolástica.

«No quería saber más de Santo Tomás y los Santos y Soto y Cano, y no novedades ${ }^{11}$. Digo que esta manera de hablar es ordinaria de todos los que saben poco y se quieren persuadir que saben mucho, y se lisonjean a sí mismos y les parece que con tener diez pares de libros llenos de polvo en su aposento, y con llamarse maestros, han satisfecho al nombre de letrados, y en el resto pueden alargar la rienda al sueño y a la buena vida seguramente. Y pluguiera a Dios que éste y los tales como éste supiesen bien esos libros con que se contentan, y aún algunos menos, porque saber solos los santos era saber muy mucho. Pero es así que dicen que se contentan con esto, no porque lo saben, sino porque tienen los libros y les parece que con tenerlos y ver de año en año en ellos cualquier renglón, acaso saben ya a santo Tomás y a los santos, que los demás libros que tocan a las lenguas y ayudan al conocimiento de la Escritura, como no los entienden ni pueden hacer creer a otros que los entienden, no los tienen y desprécianlos, que es el último consuelo de los que no tienen alguna cosa ni la esperan tener, mostrar que no hacen caso de ella» ${ }^{12}$.

A fray Luis le merecían respeto maestros como Cano o Soto, por supuesto santo Tomás, pero desdeñaba a quienes se daban por satisfechos con haberlos leído por encima o consultado ocasionalmente. En cuanto a los santos, no a todos tenía en igual estima. Celebra, por supuesto, la sabiduría de san Agustín, por la hondura que alcanza esclareciendo los misterios cristianos. En materia de exégesis, sin embargo, prefiere los trabajos de san Jerónimo. Dado que tome en cuenta para su teología a los maestros y a los santos, acepta su autoridad en forma crítica, entendiéndola subordinada a la que una y otra vez declara ser su razón de principio, es decir, la Escritura. 
Artes y ciencias en la formación de Fray Luis de León...

Ciertamente fray Luis tendía a ser particularmente crítico con el modo de enseñanza teológica de la escolástica. Le disgustaba también su método expositivo. Lo que denuncia en esa crítica es un estilo restringido de argumentar, propio de una razón consignada a dominar exteriormente objetos. Esa razón, que venía aplicándose de antiguo al campo de la metafísica, redefinida, justo por obra de los calculatores, pasará a aplicarse metódicamente al estudio de la naturaleza, dando lugar a la ciencia física. Las vicisitudes por las que discurre en los siglos modernos, con sus fases en alza y en baja, nos son al presente bien conocidas.

Fray Luis se mostrará renuente a seguir esa vía, aunque no renuncia a sus resultados. Buscará para el saber una base más comprensiva. La encuentra volviendo a lo natural originario o razón de principio de cuanto es y viene a ser. Eso natural originario es el locus, así como de toda realidad, también de todo conocimiento.

Para las fechas en que escribe era usual referirse a una antiqua sapientia o prisca theologia como sede de argumentación del saber genuino ${ }^{13}$. El de ese origen $\mathrm{y}$ no el ingeniado mediante industrias interpuestas, será el que merezca crédito en última instancia. Los otros saberes, los derivados de instancias interpuestas corresponden a tiempos que, olvidados de los orígenes, se contentan con articular residuos dispersos de conocimiento, cuyos frutos serán saberes degradados. La sanción de tal estado de cosas ha de pasar por recuperar aquel origen primero «en noche y en olvido sepultado».

En los tiempos medios en que ahora vivimos, «anda revuelto todo este negocio del hombre», escribe fray Luis. Tiempos desmemoriados, en los que los afanes de la gente, a falta de nacer, crecer y fructificar desde y en el seno de la antiqua sapientia, se distraen o pierden en fraguar moradas en lo efímero y procurarse bienes caducos. Aunque nada de eso sea despreciable, en el fondo fracasa en alcanzar lo que pretende.

\section{Asiento, forma y virtud de la sabiduría que asume todas las artes y ciencias}

La ciencia con méritos para comparecer ante la genuina sabiduría ha de entenderse como radicada en la Escritura. Ella es su documento primero e insondable, la fuente de la que todos los saberes, con títulos legítimos de tales, nacen. Sin esa razón je nacimiento, las invenciones humanas quedan en ser mediaciones sucedáneas para ocupar estériles 
discusiones académicas. En sí mismas y dejadas a sí mismas son tan vanas cuanto presuntuosas.

Ahora bien, la sabiduría que se encierra en la Escritura es cifra y resumen toda ella del ser y obrar de Cristo, germen y fruto, alfa y omega, de todo lo existente. El Texto sagrado en el que se nos hace manifiesta esa totalidad es el de una escritura signada en lenguaje crístico ${ }^{14}$. La sabiduría que entiende en ese lenguaje será la buscada, la auténtica Teología.

Naturalmente esto nos sitúa en el corazón de la religiosidad cristiana.

Antes de seguir adelante quiero hacerme cargo aquí del posible rechazo por parte de algún lector. Habrá, en efecto, quien piense que el programa que en lo dicho se esboza es desorbitado. Adelantaré sobre el particular tan sólo lo siguiente: no lo es más que el de muchos filósofos que, sobre todo en fechas posteriores a fray Luis, dejan de lado la teología, aunque para desarrollar visiones contra-teológicas que se aventuran en esbozos semejante, sólo que enraizadas en algún elemento profano. Contando con éste, no encontrarán reparo en interpretar la historia entera (con todas sus artes y ciencia) «como nacida» de ese elemento, como crecida dentro de él y asimilada a su destino: toda la historia y todos los contenidos de ella conformados por la virtud de ese nuevo Señor; mismamente, un sustituto del Cristo luisiano. Volveré en su lugar sobre este punto.Contarán en efecto con algún tipo de naturaleza originaria (cosmos material, sociedad, historia...), desde la que, como agente radical o razón de principio, explicar el entero negocio de la humanidad. Lo que varía es la concreción del elemento identificador de dicha naturaleza originaria. Fray Luis habría presentado su visión religioso-crística al caso como antídoto contra los ensayos de explicación hechos en versiones profanas.

Dos observaciones para situar la teología de fray Luis, tal como queda identificada, en el medio cultural en que vive.

Primera. En la teología en cuestión se sintetizan las virtualidades de la conciencia religiosa renacentista. En concreto la de aquel humanismo para el que esa conciencia se resumía en la philosophia Christi.

Segunda. Es una teología que rechaza la objetivación escolar de las creencias y la ritualización de las prácticas favorecidas en los siglos medios. Se valora el movimiento de época hacia la interioridad, si bien no se trata de la que desestima cuanto no sea la singularidad de uno mismo, para clausurarse en ella, lo que conduciría a la autosuficiente subjetividad moderna. La subjetividad, en casos como el de fray Luis, exige sustanciarse en un radical más sustantivo que 
ella misma. Se trata, conforme hemos hecho notar del radical-Cristo, respecto al cual podría recordarse la conocida expresión agustiniana: interior intimo meo et superior summo meo (Conf., III, 6, 11). Donde se entenderá que Cristo es para el hombre como el «alma de su alma», también pensamiento agustiniano, pero que fray Luis repetidamente hace suyo. De ahí su repudio de lo que antes he llamado «conciencia amnésica» o memoria perdida de los orígenes. Pérdida que equivaldría a olvidar en la propia existencia lo que en ellas es más radical (interior et superior) que ella misma ${ }^{15}$.

El todo de la economía de salvación cristiana puede resumirse en la sentencia repetida desde los primeros siglos de la Iglesia. También por san Agustín: Factus est Deus homo, ut homo fieret Deus (C. Litt. Petiliani, I, 7, 8). Esa cita podría dar lugar a mover una arriesgada conjetura dentro de este desarrollo. A saber, la de si no habría que ver la teología de fray Luis cargando el énfasis de tal forma en el hombre-dios que parecería rebajado el Dios-hombre; o, dicho de otro modo, acentuando la naturaleza humana asumida (deificándose) dejando desdibujada la naturaleza divina encarnada (humanizándose). La discusión de ese tema, por cierto de gran calado doctrinal, podría merecer la pena, sobre todo teniendo en cuenta los indicios inductores a tratarlo que se derivarían de una lectura atentan de la obra luisiana. Indicios como, por ejemplo, el de encontrar, entre los «estropiezos» de que fue acusado, el de haber puesto en duda la venida del Mesías. Semejante acusación, como es lógico, solivianta a nuestro fraile, aunque, en el modo como se defiende de ella, resulte revelador el hecho de que insista en honrar la humanidad de Cristo. Todo queda, no obstante, contrarrestado en ese mismo lugar al defender la tesis escotista, según la cual el Verbo se habría encarnado aún sin el pecado de Adán ${ }^{16}$.

Podemos dar aquí por identificada la personal concepción del saber que caracteriza a fray Luis, concretamente su saber teológico. Queda, asimismo, delineado en sus términos genéricos al perfil que define su modo de pensar. $\mathrm{O}$ sea aquello en que, en última resolución, se sustancia su sabiduría.

También queda indicado que esa sabiduría engloba la enciclopedia entera del momento. Esto era al menos a lo que el propio fray Luis aspiraba. Mas sabemos que no entendía la diversidad de saberes como mera acumulación externa o como algo sólo articulado por industria. Verá, más bien, las ciencias, los saberes industriados por el hombre, como orgánicamente jerarquizados y nacidos de un principio animador común y último. A tal efecto lo que hace es obra depuradora de los que encuentra a mano. Los selecciona y los organiza. El cometido 
final de esa obra es el de elaborar el humanismo teológico-crístico de que hemos hecho mención.

No es el caso de suscitar aquí la especiosa discusión sobre los méritos comparativos que encontramos en la variada obra del maestro. Y menos enfatizar los poético-literarios, que nadie discute, pero que algunos contraponen a los que se le deben como experto en ciencias sagradas, y en demérito para lo que significó en estas últimas. Como la unidad es eel pío general de todas las cosas» en lo creado (NC, I, p. 392), hemos de pensar que lo es también en sus escritos. De considerar éstos en su conjunto y vinculados a la que fue dedicación de su vida, hemos de entender que su vocación de teólogo absorbe todo lo demás. Consecuentemente, admitir que fue "antes sabio que poeta», al decir de Pfandl. O bien asentir al verso de Lope de Vega: «tu prosa y verso iguales». No casa bien con el solo poeta, al menos si atendemos a sus rimas originales (no a las versiones) el verle como "alma hebrea» (Vossler), cual corresponde a un teólogo cuya «doctrina se basaba del principio al fin en las Escrituras» (Parker), y en la que de continuo aparecen «secretas afinidades con el espíritu de los profetas y del Salmista» (Bataillon).

Atendiendo a su condición de sabio-teólogo hemos de hacer notar que lo fue no al estilo usado en las academias. $\mathrm{Y}$ eso es lo que se quiere decir al filiarse a un humanismo teológico-crístico. Más que notable su capacidad de reflexión, cuidó de equiparse con toda suerte de conocimientos. Gozaba de gran prontitud de genio para formarse opinión al discutir los problemas que ocuparon su vida universitaria. Expuso con audacia sus puntos de vista, mostrándose tenaz en mantenerlos. Era más de su agrado ocuparse en el saber teológico positivo, para el que se requerían destrezas de filólogo. En ese campo sentía moverse sobre seguro, lo que le facultaba para pronunciarse con audacia y sobre cuestiones que para el tiempo eran más que vidriosas. Tal fue el caso de las enseñanzas vertidas en su curso De fide sobre la autoridad del texto de la Vulgata ${ }^{17}$. En ese punto y otros de materia parecida fue tajante en sus juicios, a menudo contracorriente, sin que desistiera de ellos aun en los años de prisión inquisitorial. Incluso entonces, se mostró «duro de cerviz», convencido de que a la postre «la verdad y la justicia es lo que triunfa».

Se le veía, en cambio, menos inclinado a la especulación que suponía el debate de cuestiones. Sobre teología escolástica no publicó tratado alguno. Lo que en ese terreno conservamos de él son lecciones de cursos en apuntes de sus oyentes, lecciones que él nunca elaboró para darlas a la imprenta. La teología que dio al público la concibió a su 
modo, el consonante con la plática humanista, como aparece en $D e$ los nombres de Cristo. Modo abierto de tratarla, y en viva comunicación con la Escritura, su fuente. Fray Luis entiende que ése, y no el de sus contrarios, es el modo legítimo de exponerla. La escribe en romance y en estilo dialogado, conforme a los gustos renacentistas y al espíritu que representaba su generación. De esa escritura, que advertía minusvalorada por apartarse de los cánones académicos, dice:

«Los que esperaban mayores cosas de mí, si las esperaban porque me estiman en algo, yo les soy muy deudor; mas si porque tienen en poco aquestas que he escrito, no crean ni piensen que en la Teología que llaman se tratan ningunas ni mayores que las que tratamos aquí, ni más dificultosas, ni menos sabidas, ni más dignas de serlo. $\mathrm{Y}$ es engaño común tener por fácil y de poca estima todo lo que se escribe en romance...» (NC, «Dedicatoria», III, p. 672) ${ }^{18}$.

La teología por la que ahí se pronuncia fray Luis se sustancia en desvelar la insondable riqueza que se esconde en Cristo y que se pone de manifiesto en los nombres que se da a sí mismo en la Escritura. Semejante teología, según esto, no se elabora sobre categorías abstractas y edificios de razones, sino en categorías concretas expresadas en nombres. Nombres naturales, que convengan a lo que dicen como de ello nacidos; no nombres adventicios o puestos desde fuera para decirlo. De ahí que el oficio del teólogo sea más el del filólogo que el del lógico. El elemento en que, para su reflexión, se mueve fray Luis es el lenguaje. Por lo que puede calificarse su pensamiento de «onomástico». Tal manera de pensar no representa anomalía alguna si atendemos o lo que era usual dentro de las prácticas filológico-humanistas del momento. A la vez consuena con las que al presente han reactivado las filosofías de filiación hermenéutica ${ }^{19}$.

La teología que expone fray luis ofrece, pues, rasgos particulares. Es la consonante con el medio natural de la granja «La Flecha», donde la medita, por contraposición a la que se expone en las cátedras universitarias. Podría entenderse aquella como expresión de la litterata pietas, que era el ideal de los cristianos ilustrados de la época. Tendría más que ver con lo que (por servirme de una conocida distinción kantiana aplicada a la filosofía) valdría llamar «teología mundana», por contraste con la «teología académica». Aquella sería para fray Luis la genuina, y esta otra la espuria, la «desmemoriada»: «la teología que llaman», dice irónico.

Podríamos pasar ahora a decir algo, más de propósito, sobre la extensión de sus conocimientos, así como sobre el modo de administrarlos. Expondré esto en los dos apartados siguientes. 


\section{Artes y ciencias cultivadas por fray Luis}

El perfil general de lo abarcado por la formación de nuestro fraile nos lo ofrece el retrato literario que de él hizo Francisco Pacheco. Copio el pasaje en que habla de su condición de sabio.

«Famoso matemático, aritmético y geómetra; y gran astrólogo y judiciario (aunque lo usó con templanza). Fue eminente en el uno y otro derecho, médico superior, que entraba en el General con los de esta Facultad y argüía en sus actos. Fue gran poeta latino y castellano, como lo muestran sus versos. Estudió sin maestro la Pintura, y la ejercitó tan diestramente que entre otras cosas hizo (cosa dificil) su mismo retrato. Tuvo otras infinitas habilidades, que callo por cosas mayores. La lengua latina, griega y hebrea, la caldea y siria supo como los maestros de ellas. Pues la nuestra, ¿con cuánta grandeza? Siendo el primero que escribió en ella con número y elegancia..." A esta tirada de excelencias preceden las líneas siguientes, que pueden valer por resumen, y que son inmediatamente aplicadas a su profesión de teólogo: «Supo escolástico tan aventajadamente como si no tratara de Escritura, y de Escritura como si no tratara de escolástico. Fue la mayor capacidad de ingenio que sea conocido en su tiempo para todas Ciencias y Artes» ${ }^{19}$.

Es claro el estilo apologético de ese pasaje. No se trata por tanto de tomarlo a la letra, mas tampoco darlo de lado como inaprovechable. Habría que adentrarse en el escrutinio de sus escritos para ver si en ellos se confirma la superior capacidad de ingenio en todas las Ciencias y Artes de que habla Pacheco. Algo apuntaré a ese respecto más adelante. De momento añadiré otro testimonio, éste del propio fray Luis, en el que se viene a decir lo mismo. Data de 1579, de cuando, salido ya de la cárcel, oposita a la cátedra de Biblia. Dentro de un contexto en el que se refiere a su preparación y méritos para ocupar el puesto al que aspira, escribe:

«Los que me conocen y tratan saben que ha sido éste mi principal estudio desde mi niñez; y como fue este estudio siempre mi fin, así anduve siempre a él los demás mis estudios. Y porque deseaba entender las Letras divinas, y sabía que para esto era necesario, con la noticia de la Teología escolástica y con la lección de los Santos, el conocimiento de las lenguas y de la historia y de las demás letras humanas, y con ellas también la elocuencia, no comencé a aprender los principios de la gramática griega o hebraica seis meses ha, sino desde mi primera edad me apliqué al estudio de todo esto que he dicho, y no estoy arrepentido del trabajo que he puesto ni de lo que en ello he aprovechado... Cuanto al estudio de la Escritura he gastado en él casi toda mi vida» ${ }^{20}$. 
El pasaje consuena con el que (estando preso, el año 1573) en situación de tener que defenderse de la acusación de desdeñar la escolástica y los Padres, hemos transcrito páginas atrás (485-486).

No creo que sea este el lugar para ponerse a espigar páginas que acrediten en fray Luis el caudal de conocimientos que le atribuye $\mathrm{Pa}$ checo, y que él mismo pide para merecer el título de teólogo. Más importante sería hacer notar la jerarquía en que los dispone. Algo hemos dicho sobre ese particular. Mayor interés aún tendría las razones con arreglo a las cuales distribuía esa estima. Aunque vea que, con el correr del tiempo se lleguen a conocer más cosas, supedita la autoridad de la sabiduría a la antigüedad de su origen ${ }^{21}$.

En todo caso, añadir que ese cúmulo de saberes no se dio en fray Luis como resultado casual, sino como fruto de un tirocinio acucioso y perseverante, expresamente intentado. Pudo declarar de sí mismo: «Ha treinta años que soy fraile, perseverando siempre en mi religión $\mathrm{y}$ en estudios y ejercicios loables, y que ninguno de cuantos hay en ella tan ocupados y trabajados, como yo, en estudios...» Entendió la dedicación al estudio como una actividad de por vida ${ }^{22}$.

\section{Acomodo de todos los saberes dentro de su visión teológica}

Huelga insistir en que fray Luis ve siempre los conocimientos que pueden tener interés para el hombre en relación con la Escritura. Debidamente entendida, ella constituye el semillero de los saberes ${ }^{23}$. Éstos, aunque cultivados por sí mismos puedan rentar ciertas utilidades, sólo darán todo su fruto puestos a servir a la sabiduría que es su origen. $Y$ puesto que el mensaje que encierran los Textos sagrados se sustancia en declarar la economía del universo recapitulada en la misión y obra de Cristo, en «saber mucho de Cristo» se resume «cuanto el humano entendimiento puede entender y le conviene que entienda». La teología luisina, en consecuencia, será definidamente cristológica ${ }^{24}$.

Algunas ambigüedades del maestro en la exposición de ese cristologismo, y sobre todo el énfasis con que lo defiende, han dado base a ciertos de sus intérpretes para hacer derivar su doctrina hacia la visión de una "cristogénesis cósmica». Nada más fácil que hacerla deslizar en dirección de una imagen cuasi-religiosa, que hace de Dios un principio endo-cósmico. Ese principio diría exotéricamente todo lo que de verdad y virtud confesaba la fe esotérica cristiana. El hijo del hombre (el nuevo hombre), actuado en toda su potencia, vendría a hacer superfluo al hijo de Dios. La «asunción» por el mundo a través del hombre 
de la economía salvadora, ya sólo intrahistórica, evacuaría la encarnación y cuanto en ella se supone. Estaríamos ante el «Cristo de los filósofos» ${ }^{25}$. Estos serían «espíritus fuertes» que, libres de tutelas de autoridad, injertarían la obra entera de la cultura en el tronco de la emancipación del sujeto humano, vinculándola al progreso o consumación endocósmica de la especie. Así, desde Lessing o Rousseau, pasando por Hegel, hasta hoy. Ocasionalmente usurparán la hebra de esos filósofos los practicantes de unas u otras ciencias que presumirán haber encontrado en la mundanidad del hombre, en sus intereses y capacidades, la instancia última en que apoyar el edificio entero de la sociedad o de la historia. Expediente reductivo que acaba con el enigma cuya solución había ocupado a las religiones. "Dios ha muerto». «El hombre es para el hombre el ser supremo». Así, desde el Novum organum baconiano: homo homini Deus. Lo que semejante reducción evacua es el cielo religioso (también el platónico). Se dará por consumada la crítica de esos cielos, haciendo desaparecer hasta sus últimos vestigios. Queda, como consigna para el existir del hombre la «fidelidad a la tierra».

Me ocurre a veces pensar que la atracción que suscita la personalidad de fray Luis entre cierta intelectualidad (cuando le conoce) proviene de lo paradigmático que se encuentra su camino de sabio, abstracción hecha de los contenidos de su sabiduría (que, por lo común, esa intelectualidad ignora). La razón de ese atractivo, a la luz de lo indicado, resulta palmaria. La corriente de filósofos y científicos sociales aludidos traduce, de lo divino a lo humano, un pensamiento que, en esquema viene a ser el mismo. El paradigma de referencia, que era de factura religiosa, se convierte en paradigma secular. Su puesto y funciones serán las mismas. Los de un «Cristo" para el que se ofrecerán identidades varias. Desechada la que le reconoce como Verbo de Dios, vienen las que le suplen con deificaciones de esencias o potencias desdiosadas.

Volvamos de nuevo a fray Luis. Puestos en su tiempo y metidos dentro de su profesión, nada más lógico que verle relativizar el valor de artes y ciencias, de prácticas y ritos, de todo el saber y el hacer del hombre, no nacido de su fuente originaria: la sabiduría de la Escritura y el Cristo en ella revelado. Aquellas otras cosas de invención humana podrán, y hasta deberán, ser recibidas por útiles y aún necesarias, mas «no son bastantes ni poderosas» para ofrecer lo que presumen (NC, «Príncipe de la Paz», II, p. 609).

Consecuentemente con ello será la declaración propia de un profeta indignado, con que concluye su comentario castellano al Cantar. 
«En descubrir ya Cristo su luz y resplandecer enteramente por el juicio en el mundo, está el remate de todo su mando... Cada cual de nosotros, si somos miembros de Cristo y si nos cabe parte de su divino Espíritu, debemos continuamente pedirle: que le plega, aunque sea a costa y riesgo nuestro, aunque sea a costa de asolar las provincias y trocar los reinos y poner a sangre y a fuego todo lo poblado y de trastornar el mundo, rompiendo sus antiguas y firmes leyes, que le plega, allanando por el suelo los montes y cerros, venir volando a deshacer las afrentas y baldones que cada día recibe sus santo Nombre y honra» ${ }^{26}$.

Cualquiera otra instancia de unificación y consumación de lo existente, tomada de entre los elementos mundanos, al modo como puedan intentarlo las filosofías o ciencias emancipadas, con la pretensión de ser tribunal universal que todo lo juzga, se entenderá como descarrío.

Podemos cifrar ahora el núcleo de la cristología de fray Luis en la sentencia de san Pablo escribiendo a los gálatas: vivo, inquit, iam non ego, sed vivit in me Christus (Gal. 4, 20) ${ }^{27}$. He ahí la interioridad que en cada hombre es más interior a él que la de él mismo. Cristo en cada hombre es su absoluto y más íntimo ser y la fuente originaria de su virtud. Será como el alma de su alma, comunicando a ella no sólo la gracia, sino a sí mismo. Con ello se da cumplimiento a la razón de haber hecho Dios comunicación de sí mismo en lo creado, singularmente en la criatura racional, que alcanza a «hacer dioses a los hombres» (NC, «Amado», p. 747; cf. NC, «Hijo», pp. 717, 728).

Lo que se dice ahí propiamente del hombre puede extenderse a todas las criaturas, a cada una con arreglo a su grado de perfección.

«Cuanto a número de las [criaturas] que se le ayuntan [al Creador], clara cosa es que, en los bienes de naturaleza, todas las criaturas se avecinan a Dios; y solas, y no todas, las que tienen entendimiento, en los bienes de gracia; y en la unión personal, sola la humanidad de nuestro Redentor Jesucristo; pero, aunque con sola esta humana naturaleza se haga la unión personal propiamente, en cierta manera también, en juntarse Dios con ella, es visto juntarse con todas las criaturas, por causa de ser el hombre como un medio entre lo espiritual y lo corporal, que contiene y abraza en sí lo uno y lo otro; y por ser, como dijeron antiguamente, un menor mundo o un mundo abreviado» (NC, «Pimpollo», I, p. 412; cfr. De Incarnatione (Opera, IV), pp. 25-27).

Visión religiosa que tienta, en efecto, a hablar de un «Cristo cósmico», y que, de no renunciar a servirse de ese lenguaje, sería mejor traducirlo por el de un «cosmos crístico» ${ }^{28}$. Tal es el medio en el que se expresa el «pío general de todas las cosas». 
Desde esa concepción teológica, que tiene a Cristo, en lo absoluto, «enteramente por el juicio del mundo», será la cuestión de entender los juicios que contienen los saberes que se mueven en lo relativo. No se niegan las artes o las ciencias, pero advirtiendo que, dejadas a sí mismas y a lo que de suyo pueden, no bastan a satisfacer aquel pío general de las cosas. Cerradas en su propia lógica, incluida la teología con su lógica escolar, tendrán el título de ciencias o artes, pero sin la genuina realidad de tales.

Aplicando ese criterio, las ciencias y las artes le merecen a fray Luis tanto menos crédito cuanto de creación más nueva o de mayor artificio.

En este punto su modo de pensar puede sonar a arcaizante. La antigüedad de una manifestación de cultura se acepta por legitimadora de su autoridad. Lo que ocurre, tanto si se trata de los oficios u ocupaciones artesanas, como si se atiende a las doctrinas (ciencias), o bien a las prácticas (política). Los que se tienen por «adelantos» en cualquiera de esas esferas, en resumidas cuentas y todo contado, serán simplemente invenciones espurias al no originarse en el principio del que están llamadas a nacer.

Mas la vuelta a los orígenes que propone fray Luis casa mal con la acusación que se le hizo de ser «amigo de novedades». Habrá de tomarse esa «vuelta» en el sentido de evitar o corregir el curso seguido por unas culturas que, sea debido a su origen o bien a su ejercicio, aparecen viciadas. El arcaísmo de que puede hablarse al respecto, como lo prueban intentos análogos posteriores, en realidad será lo contrario: germen de renovación y de progreso. Hecha la anterior observación sorprenderá menos ver a nuestro autor pronunciarse, contra las invenciones «modernas», por "lo antiguo, humilde y llano».

Así, respecto al cuidado de la naturaleza, antepone la agricultura a la industriosidad o las mercaderías ${ }^{29}$. En lo que toca a las cosas morales, relega aquellas prácticas que se contentan con poner fomentos por fuera (remedios ascéticos y observancias externas), privilegiando las que conducen a la animación interior. En lo político, critica los regímenes ordenados bajo leyes puestas o mandatos de autoridad, anteponiendo a ellos el que entiende como "gobernación de la ley viva» ${ }^{30}$. Le vemos, en un extremo, mostrando el oficio de pastor solícito por su rebaño como ejemplo de lo que ha de ser el gobernante atendiendo al pueblo que rige. En el extremo contrario, ironiza, sobre las bondades que pueden encerrar inventos como el de ingeniar una torre para elevar el agua desde un río ${ }^{31}$.

Por arcaizantes de parecido linaje habría que tener a pensadores más cercanos a nosotros, y tan influyentes como Vico o Rousseau, 
Marx o Freud, Nietzsche o Heidegger... La nota de arcaísmo no mermaría su significación intelectual. No los veríamos ocupados en retrasar el reloj de la historia. Lo que con esa nota se indica es su oposición a «progresos» mal encaminados. Los derivados del espíritu moderno, sobre todo si se identifica con el tipo de conocimiento característico de lo que en ese periodo se entendió por ciencia. Sabemos que esa ciencia elimina cuanto signifique entender la naturaleza ex analogia hominis, en el sentido de desalojar de ella todo vestigio de alma. Lo que tiene que ver con el alma quedaría para los discursos que se pronuncian extrafuero de la ciencia. Es como en ese periodo moderno vino a consagrase la escisión de las llamadas «dos culturas»: cultura científica/cultura humanista.

\section{Una teología que toma partido}

Terminaba la sección precedente introduciendo el tema de las «dos culturas». Habría que distinguirlas, desde luego, por los contenidos en ellas cultivados, pero también, y antes que nada, por el modo de hacerlo, o sea, por la diversa disposición mental ante la realidad.

La incómoda posición que fray Luis mantuvo en su carrera universitaria, a causa de lo que él llamaba «pleitos y pretendencias de escuela», así como las denuncias y la cárcel que sufrió, no se debían a que profesase unas $u$ otras doctrinas. Aunque algunas de éstas pudieran ser audaces o peligrosas para ser expuestas a la sazón, por ninguna de ellas fue condenado. Lo que le convirtió en sospechoso fue el tipo de mentalidad que le definía, y el haber tomado partido por la cultura de ella derivada.

Desde el comienzo de estas páginas hemos ido viendo aparecer la contraposición entre escolásticos y humanistas.

Se concreta ahí la dualidad de culturas antes mencionada. Dualidad, ahora en vías de secularizarse, que era herencia de la que se vivió en centurias anteriores, especialmente en los siglos XII y XIII, al tiempo de recuperarse la filosofía de Aristóteles y cuajar el método escolástico. Se trata, por una parte, de la tradición sapiencial de los «santos» $y$, por otra, de la racionalización de ella (en el sentido weberiano) por obra de los maestros universitarios. Valdría denominar «humanista» a la primera y «científica» a la segunda ${ }^{32}$.

En cualquier caso, no se entiende, al menos eso ocurre en fray Luis, que filiarse a una de tales discencias suponga exclusión de la otra. Dejada cada una a su propia dinámica, y extremando ésta, se 
abocaría a la situación a que se llegó al final de los siglos medios: escolástica formalista e inánime de los nominales, contra la sabiduría vivencial e inarticulada de la devotio moderna.

Para una teología completa y madura habría de contarse con la doble tendencia, aunque quedara abierto el problema de decidir a cuál de ellas dar en última instancia la primacía.

Conocemos la opción de fray Luis. A saber, la sabiduría practicada por los «santos», resuelta a su vez en el conocimiento de la Escritura, y en entender al servicio de ésta lo demás. Sustanciado todo ello en «saber mucho de Cristo». Ya en ese terreno, notamos cómo tendió a poner el acento en su obra deificadora del hombre y recapituladora de todo lo creado. También, que esa obra no puede cumplirse fuera del supuesto de la encarnación. A la deificación del hombre previene la humanización de Dios. Comprendía muy bien el maestro que nada podría ser cosechado como consumación si nada había sembrado como incoación. Cristo: raíz-fruto, alfa-omega. El capítulo «Pimpollo», dentro de los Nombres, contiene su argumentación esencial a este propósito.

Estas afirmaciones se hacen con toda naturalidad. Pero en ellas se tocan o insinúan los problemas más arduos de que siempre se ocupó la Teología. Son, por lo que atañe a la cristología, los de la naturaleza divina encarnada y la naturaleza humana asumida (dos naturalezas en una persona), y por lo que se refiera a la obra ad extra de la Trinidad, los de la creación y la redención. Ulteriormente habrá que estudiar el modo de relacionarse la doble dimensión teológica que entra en juego. Creación y redención pueden llegar a entenderse de tal manera que cada extremo haga innecesario al otro. Lo mismo vale para el caso del Verbo humanándose y el hombre deificándose. La historia del dogma acredita la dificultad que ha supuesto articular los dos lados de cada cuestión.

He aludido antes a filosofías que, a modo de cuasi-religiones en lo profano, se pronuncian por alguna suerte de redención sin creación, o bien fomentan procesos divinizadores de la humanidad excluyendo cualquier presencia de virtualidades divinas. En situación parecida se encuentran las últimas cuestiones filosóficas. En el campo epistemológico, por ejemplo, hay una concepción de la ciencia cuyo modelo es la acción creadora, que ordena según número, peso y medida lo informe. Lo que se asemeja al proceso de encarnación de algún lógos; y hay la otra concepción (también de la ciencia), que respondería al modelo de redimir, y que habría que asociar a procesos de autorrealización. 
Añadiré a este respecto un inciso para salir al paso de lectores que puedan tachar de forzado el acercamiento que aquí hago del pensamiento de fray Luis, en lo que tiene de énfasis en la originaria virtud de Cristo para la obra de consumación humana, al de las filosofías praxiológicas posteriores. Presentar las cosas bajo ese ángulo permite tocar en su núcleo más vivo la originalidad de su obra. Por otra parte, dicho acercamiento creo que puede tener un efecto clarificador de las respectivas visiones de la realidad, no sólo la del maestro salmantino.

¿Y que decir de la utilización de nociones que nombran dogmas religiosos para discernir posiciones tocantes a campos de investigación que caen dentro de lo profano? Recordaría a este respecto la sorpresa de Proudhon al ver de continuo presente la teología en el fondo de las discusiones políticas. Y seguiría preguntando: ¿por qué sólo en el fondo de las cuestiones políticas? ¿No sucede lo mismo con la filosofía? Me gustaría conocer el modo de rebasar ese horizonte teológico al interesarse por la última razón de la ciencia o, generalizando, por cualquier manifestación de la cultura. Incluyendo en todos estos casos las versiones contrapuestas que sus problemas reciben.

Será ya cuestión de cerrar mi discurso, Mas no quiero hacerlo sin referirme a un nuevo cuadro de categorías, usado también por fray Luis para ofrecernos su visión de la realidad, y que parece no concordar con las del cuadro en que hasta ahora hemos insistido. Aludo a la recepción que en él encontramos de la cultura pagana, en concreto la de tradición greco-platónica.

La contraposición se establece aquí entre el mundo de la idea y el de la materia. Elemento divino el primero y mundano el segundo. En Platón el mundo de la idea recibe absoluto privilegio. Su comunicación con el de la materia será apenas una sombra de presencia en él. Lugar éste del olvido, entra en juego el ejercicio de la reminiscencia o memoria de la región de la verdad y el bien, el único a salvo y sin que lo de fuera pueda salvarse. Para la materia, nulla est redemptio. La visión platónica admite un modo de creación, mas no deja espacio a la redención. Ofrece un remedo de la encarnación, pero sin que lo pálidamente encarnado tenga virtud asumptiva deificadora.

Esta esquemática da un aire a la doctrina teológica que hemos visto expuesta por fray Luis. Ello le permite aprovecharlo, aunque tenga que someterlo a transformación.

En ciertos pasajes de la obra luisiana aparecen la contraposición platónica aludida. Ocurre como respuesta a la condición de olvido en que la humanidad se ve sumida. Pero olvido ¿de qué? 


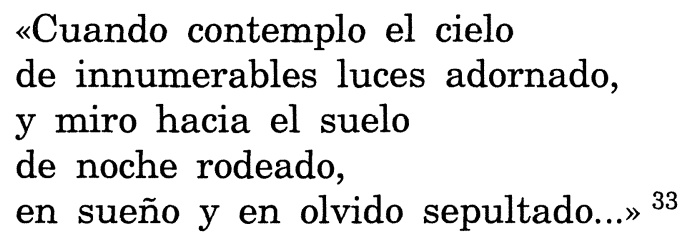

Cielo/suelo, luz/noche, bien divino/cárcel oscura... Dos mundos que parecen incomunicados. En medio, la tensión del alma que suspira por el primero y huye del segundo. ¿Cómo entonces se hace posible la redención o el proceso de deificación? Pregunta semejante puede provocar una subverción de los aprecios. Puesto que donde estamos es en el lado de acá, y lo que ahí ocurre es lo que realmente nos concierne, busquemos nuestra propia manera de redimirnos y deificarnos. Busquemos realizarnos en y con lo que tenemos, sin ayudas divinas ni señuelos celestiales. Gran parte del pensamiento contemporáneo expone una visión contra-platónica. Supone, de nuevo aquí, una radical «crítica del cielo».

El desafío que semejante situación supone para un teólogo no requiere ser enfatizado. Fray Luis se ha situado de entrada en la otra orilla. Su problema será el de ver el modo de aceptar a Platón, sin que implique renunciar a Cristo. Nuestro autor rechaza la crítica reductora del cielo. Acepta el dualismo platónico, pero lo resuelve recurriendo al agonismo de Cristo que hace del alma su «vivienda» y la capacita para recuperarse del olvido en que está sumida en el suelo y luzca su memoria del cielo.

En efecto, entiende el alma compuesta por dos partes: una divina, que mira al cielo; otra, que mira a la tierra y se comunica con el cuerpo. Son de condiciones contrarias. De ordinario se hacen guerra. En el cuadro que ahí se nos presenta parece que la armonía va a ser desesperada. Es cuando entra en escena Cristo comunicando al alma su ley, su virtud y su persona misma. Viene primero de asiento a su parte más elevada, pero asume también a la que mira a la tierra. Procede purificándola y elevándola por grados, que reflejan los de su nacimiento y crecimiento en ella: los de principiantes, aprovechados, perfectos, hasta hermanarse los contrarios.

«... En nuestra alma, como sabéis, hay dos partes: una divina, que de su hechura y metal mira al cielo, y apetece cuanto de suyo es, si no lo estorban u oscurecen o llevan, lo que es razón y justicia: inmortal de su naturaleza, y muy hábil para estar sin mudarse en la contemplación y en el amor de las cosas eternas. Otra de menos quilates, que mira a la tierra y que se comunica con el cuerpo, con quien tiene deudo y 
Artes y ciencias en la formación de Fray Luis de León...

amistad, sujeta a las pasiones y mudanzas de él, que la turban y alteran en diversas olas de afectos... Estas dos partes son como hermanas nacidas de un vientre en una naturaleza misma, y son de ordinario entre sí contrarias, y riñen y se hacen guerra... Y son propiamente la una como el cielo, y la otra como la tierra...

Cuando el alma aborrece su maldad y Cristo comienza a nacer en ella, pone su espíritu como decíamos, en el medio y en el centro, que es en la sustancia del alma, y prende luego su virtud en la primera parte de ella, la parte que, de estas dos que decíamos, es la más alta y la mejor. Y vive Cristo allí en el primer estado de este nacimiento... Y este es el estado segundo que dijimos, en el cual el espíritu de Cristo vive en las dos partes del alma; en la primera que es la celestial, santificándola o, si lo habemos de decir así, haciéndola como Dios; y en la segunda que mira a la carne, apurándola y purificándola de lo carnal y vicioso...» ( $\mathrm{Y}$ así, hasta que por fin) «se hermanan las dos partes del alma que decimos, y el sentido ama servir a la razón». ( $Y$ Cristo), "que nace y vive en estas dos partes» (hace verdad el dicho de san Pablo): "Vivo yo, ya no yo, pero vive en mí Jesucristo» (Gal. 4, 20). (NC, «Hijo de Dios», pp. 721-723, 728) ${ }^{34}$.

Pasaje largo, pero que va a ser el último que citemos. En él se dice cuanto tiene de nuclear la teología de fray Luis.

\section{En conclusión}

En las páginas precedentes hemos presentado a fray Luis de León formando parte del grupo de intelectuales y estudiosos que prestigian nuestro siglo XVI. Es, en concreto, personalidad relevante de la que distinguimos, por razón de la fecha de su nacimiento, como «generación del 27». Queda señalado lo que de singular dentro de ella tiene su pensamiento. En concreto su diferencia con el oficial, junto con la relación ambivalente que mantuvo con él, con la escolástica académica. De paso, me he referido al aparente arcaísmo de ese pensamiento, y a cómo, no obstante, advertimos una marcada afinidad entre él y el que ha venido a ser dominante, cambiada a clave profana la que fuera religiosa, en significativas corrientes filosóficas posteriores.

La teología luisiana era definitivamente cristolégica. Dentro de esa teología es básica la doctrina del Verbo que se encarna y la de la naturaleza humana por El asumida. Dios se hace hombre para hacer al hombre Dios. Dicho en otros términos: El cielo se allega a la tierra; mas no para quedar forastero-rostro-pálido en ella. La habita (habitar transitivo, no acampar estacionado) hasta volverla cielo... 
El equilibrio deseable entre los opuestos que ahí aparecen no es fácil de conseguir.

Indicábamos que el propio fray Luis deja una sombra de ambigüedad al respecto debido al acento que pone en el proceso deificador del hombre. Un desequilibrio en contrario podría achacarse a la Teología escolástica que, tal como se presenta en su forma oficial, ha podido ser acusada de defender en tal forma la soberanía de Dios que desconoce o niega la realización del hombre.

El debate de ideas, sus críticas y contracríticas, en este ámbito en que se dirimen últimas posiciones ante la realidad, ha dado en la historia mucho juego. Partidas «entre sí contrarias, que riñen y se hacen guerra», son las de un ciencismo académico contra un humanismo mundano. Del primero, que, en la circunstancia de fray Luis, era el escolasticismo estricto, de extremarse, no habría que esperar otra cosa que el título de ciencia sin realidad. El caso segundo nos lleva al polo opuesto. Es el de aquellos que, al presente, ofician de posmodernos radicales y se conducen respecto al «desiderario» («sin astros» moderadores) de los humanos del mismo modo que lo hicieran los alumbrados del tiempo de fray Luis con la caótica de sus almas.

Semejante situación fue entonces, como lo es ahora, provocadora de malestar, para la que, igualmente, entonces como ahora, se buscó o busca alivio. Ello plantea el problema de encontrar una vía media que posibilite llevar a coincidencia los opuestos.

Las páginas que preceden han tratado de mostrar cómo resuelve Luis de León ese problema. Es ilustrador al respecto ver cómo lo hacen con posterioridad a él aquellas filosofías que, si bien sobre supuestos antagónicos, practican estrategias argumentativas similares.

Sea ejemplo de esto último Herbert Marcuse, filósofo mundano (fiel a la tierra, si los hay). Tomemos como obra característica suya Eros y civilización. Notemos cuál es el elemento originario en que se mueve (eros), y cómo encuentra opuesto a él la «civilización». Todo su problema consistirá en resolver la tensión entre los dos principios (en diálogo con Freud: principio del placer/principio de la realidad), lo que se conseguirá sólo si se llega a entender el segundo «como espontáneamente nacido» del primero, no exterior a él y reprimiéndolo.

$\mathrm{Al}$ referirme al caso de Marcuse intento simplemente sugerir que el modo de pensar que refleja en su obra y el movimiento que la imprime son análogos a lo que dejamos descritos con relación a fray Luis. Sólo que éste se mueve en un medio religioso celeste, y aquél en el opuesto terrenal profano: un cristo mundanal erótico, contra el Cristo celestial Logos ${ }^{35}$. 
Fray Luis de León, por otra parte, es muestra de cómo conseguir armonizar las dos tradiciones culturales a la sazón en activo: la profética (hebrea) y la filosófica (griega). Las armoniza privilegiando la tradición hebrea. Lo que habría sido dificultoso, de contar únicamente con el mesianismo terrenalista del Antiguo Testamento. Se hace viable esa posibilidad al entrar en cuenta el Testamento Nuevo, que, para la ocasión presente, podemos ver sintetizado en el prólogo al Evangelio de san Juan. El Mesías celeste se encarna, asume la naturaleza toda, singularmente la humana, y se constituye en vínculo de comunión universal. Comunión entre patria (suelo de lo que se genera) y el reino (cielo de lo inmortal divino).

Tal es la especie singular de «odisea» (ya que, en fray Luis, como tal, y no como cortante «éxodo», ha de figurarse el destino de «toda esta fábrica del Universo»), en cuyo ámbito han de entenderse producidas, «como nacidas», nuestras Artes y Ciencias, cuanto entendemos por cultura humana. Entenderemos asimismo que todo es de la casta de la que de raíz viene; tendrá la forma del principio animador común; y a la consumación de ese principio se ordena. En esto se resuelve el radical-cristianismo luisiano.

\section{Notas}

1 Con el mote de «tibetanización» aludo al diagnóstico cultural del periodo, hecho por J. Ortega y Gasset: Obras completas, Alianza Editorial-Revista de Occidente, Madrid, 1983, VIII, págs. 355-356; Ibid., pág, 87; Obras, IX, pág. 133.

2 Cfr. BATAILLON, M.: Erasmo y españa. Estudios sobre la historia espiritual del siglo XVI, Fondo de Cultura Económica, México, 1966, págs. 721-723, 738 ss.; para fray Luis de León, págs. 760-769.

3 ANDRES, M.: Historia de la mística de la Edad de Oro en España y América, BAC, Madrid, 1994, pág. 68.

4 La frase entrecomillada figura como título de la colaboración de María Paz ASPE en Homenaje a Pedro Sainz Rodríguez, Fundación Universitaria Española, Madrid, 1986: IV, «Estudios teológicos».

5 Sobre la enumeración que sigue puntualizaría dos cosas. Primera: El asociar los números 1 y 2 a los nombres de Bartolomé de Medina y Benito Arias Montano se debe a que se trata de personajes cuyas biografías se cruzan insistentemente con la de fray Luis. Se hace de Medina el representante de la escolástica, porque como tal figuró en la historia que aquí interesa. Es sabido, además, que el fraile dominico fue, junto con León de Castro, el acusador más enconado del agustino ante la Inquisición. Véase, para esto, Colección de documentos inéditos para la Historia de España, por Miguel SALVÁ y Pedro SAINZ DE BARANDA, Madrid 1847, vols. X-XI. Las declaraciones de Medina y Castro, en X, págs. 5-18, y passim. (Cuando, en adelante, se cite esta Colección se hará abreviando el título en : DI.) Hay edición reciente de esos "Documentos»: El proceso inquisitorial de fray Luis de León, ed. intr. y notas de Angel ALCALÁ, Junta de Castilla y león, Salamanca, 1991. 
Puntualización segunda: se dan en la época otras corrientes de ideas. Para mi exposición son subsumibles en las indicadas. Aparecerán en el desarrollo, en todo caso, aquellas escuelas antiguas que renacen a la sazón, entre las que deberá tenerse en cuenta de modo particular la platónica. (Nótese que los nombres que pueden representar a platónicos y aristotélicos son S. Fox Morcillo, nacido en 1528, y G. Cardillo de Villalpando, en 1527; los dos, por tanto, de la generación de fray Luis.)

6 Dentro de ese pensamiento puede fray Luis hacer de los poetas los teólogos de los gentiles: «Unde videmus narrationes poëtarum, qui fuerunt veluti theologi gentilium..." (Tractatus de sensibus sacrae Scripturae, en Reportata Theologica [Opera, IX], Ediciones Escurialenses, Real Monasterio de El Escorial-Madrid, 1996, pág. 643; cfr. CURTIUS, E. R.: Literatura europea y Edad Media Latina, Fondo de Cultura Económica, México, 1989, I, cap. XII: «Poesía y teología», pág. 305 ss.; SÁNCHEZ SALOR, E.: "Reflejo de la Biblia en la cultura profana latino-medieval», en Revista Agustiniana, XLIII [2002], págs. 127-128; cita en esta última página: «Dunque bene appare, non solamente la poesia essere teologia, ma ancora la teologia essere poesia" (texto de Boccaccio, que se encuentra también en Curtius, Ob. cit., pág. 322).

7 Para esos hebraístas y la suerte que corren, común con la de fray Luis, ver DI, en concreto la declaración de León de Castro: DI, X, págs. 7-9; también la declaración de Gaspar de Uceda: Ibid., págs. 24-26; insistencia de los mismos, pág. 260 ss. Las respuestas de fray Luis, Ibid., pág. 317 ss. Para los textos del proceso originales de fray Luis me serviré de Fray Luis de León, Escritos desde la cárcel. Autógrafos del primer proceso inquisitorial, edición y estudio por José BARRIENTOS GARCIA, Ediciones Escurialenses, Real Monasterio de El Escorial-Madrid, 1991 (citaré en adelante esta obra abreviando el título en EC). Las causas seguidas contra los otros dos hebraístas, en: PINTA LLORENTE, M. de la: Procesos inquisitoriales contra Gaspar Grajal, El Escorial-Madrid, 1935; ID.: Proceso criminal contra el hebraista salmantino Martín Martínez de Cantalapiedra, Instituto Arias Montano, Madrid, 1946; para una visión de conjunto, ALCALA, A.: "Peculiaridad de las acusaciones a fray Luis en el marco del proceso a sus colegas salmantinos", en Fray Luis de León. Historia, Humanismo y Letras, eds. de Víctor García de la Concha y Javier San José Lera, Ediciones Universidad de Salamanca..., 1996, págs. 65-80.

8 La datación NC, que figura en el paréntesis, abrevia el título De los nombres de Cristo, lo que se mantiene en adelante. La edición por la que citaré los escritos en romance de fray Luis es la siguiente: Fray Luis de LEÓN: Obras completas castellanas, ed. de Félix García, O.S.A., BAC, Madrid, 1944. Incidiendo en los motivos que aparecen en el pasaje acotado, fray Luis denuncia el error en que se encuentran aquellos que,"ignaros de las Letras divinas", enseñan o gobiernan; y declara su intención de elaborar un escrito sobre el particular. "De istorum perverso errore, proprio et iusto volumine aliquando fortasse dicemus» (In Canticum Canticorum [Opera, II], Salmanticae, 1892, pág. 210). Al recusar a determinados maestros como calificadores de su doctrina (aparte de los que pudieran estar afectados de alguna rivalidad contra él) da como razón lo siguiente: «En los demás teólogos que quedan fuera de los sobredichos hay algunos que no tienen la libertad que es menester para decir lo que sienten acerca de mi lectura de la Vulgata, por estar atemorizados con mi prisión y las demás que se han hecho debajo de este último; y otros que, aunque tienen el nombre de teólogos, no tienen las letras que se deben a aquel nombre, ni las que parecen ser necesarias para dar parecer acerca de mi doctrina” (EC, pág. 272).

9 Cfr. EC, págs. 138-139. Ver NC, «Dedicatoria», pág. 385. 


\section{Artes y ciencias en la formación de Fray Luis de León...}

10 Ibid., pág. 138.

11 Redarguye ahí fray Luis a la contestación que dio uno de los teólogos a quienes había enviado su lectura sobre la Vulgata pidiendo su aval o su dictamen. El envío se había hecho a Sevilla, a través del agustino Francisco de Arboleda, lector en el convento de su orden en aquella ciudad. Más que pareceres serios obtuvo evasivas. Entre ellas, la de "un racionero de Sevilla de cuyo nombre no se acuerda" (el declarante padre Arboleda), que nada le dio por escrito, pero le dijo de palabra: "No quisiera yo que vos hubierais dicho esto, porque sois mi amigo; que aunque no quita cátedra ni púlpito, quita sueño; que yo no quiero saber más de lo de santo Tomás, y los Santos, y mis maestros Soto y Cano, y no novedades, y que el padre fray Luis tenía émulos, y dio a entender a éste que tenía raza de judíos el dicho fray Luis..." (DI, $\mathrm{X}$, pág. 38). Es de notar que aquellos de quienes esperaba opinión sobre su lectura quería fray Luis que supiesen "griego, hebreo y teología» (Ibid.).

12 EC, pág. 146.

13 El supuesto de una sabiduría que viene de los orígenes de la humanidad, entonces plena, y con el correr del tiempo oscurecida, fue lugar común entre los antiguos autores cristianos; en él se basaba la opinión de aquellos que entendían derivada de esa sabiduría la de los filósofos, significada en Platón. En el Renacimiento hubo quienes recuperaron esa creencia, como es el caso de Agustín Steuco, autor muy leído en la época y frecuentemente citado por fray Luis; lo hace especialmente en su obra De perenni philosophia, sintagma acuñado por el propio Steuco y de amplia circulación posterior (Augustini STEUCHI EUGUBINI..., De perenni philosophia [Opera, III], Venetiis, 1591, varias ediciones anteriores), passim, desde el cap. I: «De successione doctrinae ab exordio mundi». En esa idea comulgaban los platónicos florentinos. En Ficino la vemos asociada a su interpretación de Platón y a los libros herméticos, traducciones ambas hechas por él. "La continuidad de la tradición platónica asume una nueva importancia para Ficino. Como se piensa que esta tradición se remonta hasta Hermes y Zoroastro, es tan antigua como la tradición religiosa de los hebreos, y así la tradición religiosa de los hebreos y cristianos y la tradición filosófica de los seguidores de Hermes y Platón corren un curso paralelo en la historia humana, que va desde los primeros principios a través de la Antigüedad y la Edad Media hasta el periodo moderno. De conformidad con esta visión de Ficino, Agustín Steuco, teólogo católico del siglo XVI, escribió De perenni philosophia (1540)» (KRISTELLER, P.O.: Ocho filósofos del renacimiento italiano, Fondo de Cultura Económica, México, 1985, pág. 72).

14 Cfr. ALVAREZ TURIENZO, S.: «El argumento y suma de la Teología es Cristo. Escritura luisiana y clave de lectura", en Escritos sobre fray Luis de León, Ediciones de la Diputación de Salamanca, 1993, págs. 217-245.

15 Fray Luis resume la economía entera de la salvación en estas dos expresiones: «nacer nosotros de Cristo" y «nacer Cristo en nosotros». Nótese la repetición de la palabra "nacer", como algo interior y vivo. «Como nacido» de su principio entenderá todo aquello que es genuino y verdadero, contra lo artificioso, que viene puesto desde el exterior. Para ese nacer Cristo y nacer de Cristo, véanse los capítulos «Padre del siglo futuro» e «Hijo de Dios", en De los nombres de Cristo. Ello lleva a hacer de Cristo "alma del alma", como se indicará en el texto, hasta la deificación de los hombres (NC, "Amado", pág. 747). Un texto, por los muchos que podrían aducirse: "La gracia es una como deidad y una como figura viva del mismo Cristo, que, puesta en el alma, se lanza en ella y la deifica, y, si va a decir verdad, es el alma del alma» (NC, "Príncipe de la paz», pág. 612). 
16 Para las acusaciones dichas, DI, X, págs. 76-80; para la respuesta de fray Luis, Ibid., págs. 384-388; EC, págs. 156-160. Ahí mismo formula su tesis sobre la encarnación, aún sin el pecado. Ver De incarnatione tractatus (Opera, IV), Salmanticae, 1893, págs. 31-34. Cfr. MUÑOZ IGLESIAS, S.: Fray Luis de León, teólogo, CSIC, Madrid, 1950; FOLGADO FLÓREZ, S.: Cristocentrismo teológico en Fr. Luis de León, Real Monasterio de El Escorial- Madrid, 1968.

17 La Reforma de Lutero removió las aguas en torno a cuanto se refería al Texto bíblico. Surgieron naturalmente cuestiones en torno a la versión Vulgata, cuya autenticidad sería sancionada en Trento. Entre tanto se ensayaban versiones más ajustadas a los originales. Tal fue el caso de la conocida como «Biblia de Vatablo». En ese agitado medio se verá envuelto fray Luis, quien, dada su formación, se implicará a fondo en los debates al caso. La documentación del proceso inquisitorial pone de manifiesto que sus opiniones sobre ese asunto de la Vulgata vinieron a ser las que más dañaron la favorable resolución de su causa. Para comprobarlo basta repasar los protocolos de dicha causa, incluyendo lo que toca a la "Biblia de Vatablo", con la revisión que se mandó hacer de la misma, en vistas a su posible impresión, en Salamanca (cfr. DI, X, passim; para la "Biblia de Vatablo" y, en general, para todo el enredo de la Vulgata, visto por la cara adversa, consultar la declaración de León de Castro (CI, X, págs. 7-18). Para la respuesta de fray Luis, por la cara de su defensa, Ibid., págs. 326-357; EC, pág. 110 ss. Cfr. GONZÁLEZ NOVALÍN, J. L.: «Inquisición y censura de Biblias en el Siglo de Oro. La Biblia de Vatablo y el proceso de fray Luis de León", en cit. Fray Luis de León. Historia, Humanismo y Letras, págs. 125-140.

18 Ver las "Dedicatorias" a los tres libros De los nombres de Cristo y, en general, los "prólogos» a sus otros escritos. En esas páginas da cuenta de cuáles eran sus más personales preocupaciones, junto con los criterios y métodos de que usaba para tratarlas.

19 Casos como, por ejemplo, el de H. G. GADAMER. «Todo lo que hay que presuponer en la hermenéutica es únicamente lenguaje». Lema que Gadamer toma de Schleiermacher y que incluye en su obra Verdad y método (Ed. Sígueme, Salamanca, 1984, pág. 460). Fray Luis podría haber hecho suyo ese mismo lema (cfr. ÁLVAREZ TURIENZO, S.: «Cosas y nombres en fray Luis de León", en La Ciudad de Dios, 198 [1985], págs. 833-880). Con todo, y ante la caracterización del currículo formativo de fray Luis, que se hace en el texto, no sobra insistir en que fue un titulado académico normal; cursó teología escolástica, impartida por maestros de prestigio, así como los estudios preparatorios para acceder a ella; la enseñó además durante varios años en las aulas, considerándose él mismo a la altura de cualquiera de sus competidores en ese campo. Mas nos recordará también que tales estudios, aunque necesarios, tienen valor sólo dentro de ciertos límites. (Sobre la indicada formación universitaria de fray Luis, ver BARRIENTOS GARCIA, J.: Fray Luis de León y la Universidad de Salamanca, Ediciones Escurialenses, Real Monasterio de El Escorial, Madrid, 1996; también BELL, Aubrey F.G.: Fray Luis de León, Un Estudio del Renacimiento español, Ed. Araluce, Barcelona, 1927.)

20 Plática en la oposición a la cátedra de Biblia, 28 de noviembre de 1579, en Fray Luis de LEON: Epistolario. Cartas, licencias, poderes, dictámenes, ed. por José Barrientos García, Editorial Revista Agustiniana, Madrid, 2001, págs. 152-153. Muestras de los variados intereses intelectuales de fray Luis, en BELL, A. F. G.: Luis de León. Un estudio del Renacimiento español, Araluce, Barcelona, 1927, cap. XI. pág. 273 ss. 


\section{Artes y ciencias en la formación de Fray Luis de León...}

21 Ver nota 13.

22 EC, pág. 158; cit. Epistolario, pág. 158.

23 «Ex quo intelligimus sacras Litteras, non solum moralis ac supernaturalis doctrinae scientiam includere, sed etiam continere semina cum naturalis philosophiae, tum reliquarum artium atque scientiarum» (In Ecclesiastem expositio [Opera, I], Salmanticae, 1891, págs. 294-295).

24 "Argumentum omniun Scripturarum et summa earum est Christus" (Expositio in Genesim, "Reportata" de sus explicaciones de clase, curso 1589-1590, inédito; ver su presentación por K. Reinhardt, en La Ciudad de Dios, CCIV [1991], pág. 994; cfr. Notas 14 y 16). Ahora bien, el argumentum-Cristo no queda en ser una invocación indefinida. "Saber mucho de Cristo" es cuanto le conviene y le es necesario al hombre saber, y eso lo encuentra dicho en los "nombres" que la Escritura le da (habla de los que convienen a Cristo en cuanto hombre), entendiendo que ellos encierran todos los tesoros de bien que su naturaleza tiene y las obras que Dios hace por ella. A declarar cuanto en esos nombres se significa dedica fray Luis su obra, aunque limitándose a los más "sustanciales" (NC, cap. I, pág. 403)

25 Xavier TILLIETTE ha desarrollado un amplio plan de estudios bajo el título de Le Christ des philosophes; un esbozo del camino que sigue su investigación, «El Cristo de la Filosofía", en Jesucristo, hoy, Cursos de Verano, El Escorial, 1989, Salamanca, 1990, págs. 283-295. Entiéndase lo que aquí se insinúa en el texto y lo que, en la misma línea, ocurra decir más adelante sobre unas u otras filosofías que, en versiones seculares, se asocian al modo como fray Luis piensa su "cristocentrismo", no como tema que directamente se discute, ni como juicio (y menos personal) pro o contra tales filosofías, sino como punto sólo "concurrente" y con valor de elemento de contraste para determinar el canon dentro del que la religiosidad del maestro salmantino se mueve.

26 Cantar de Cantares, en Obras completas, pág. 174. Juzgado fray Luis a la luz del texto citado no daría la imagen del "anarquista agustiniano", que de él hace Unamuno, « del carácter «libertario» que, con Joaquín Costa, le atribuye Américo Castro. K.R. Popper habría encontrado en él razones para incluirle en la lista de los "enemigos de la sociedad abierta». Pero eso mismo pasa con otros «libertarios" con los que se le ha relacionado, por ejemplo, Rousseau.

27 Fray Luis de LEÓN: In Epistolam Pauli ad Galatas (Opera, III), Salmanticae, 1892, págs. 271-273; NC, «Hijo de Dios», pág. 738.

28 Lo de "Cristo cósmico" induciría a pensar en un mundo sacralizado de suyo, en coincidencia con lo que ciertas escuelas filosóficas paganas (platónicos, estoicos) entendían por "religión cósmica». El "Sueño de Escipión", que cierra el escrito ciceroniano De republica, es el mejor resumen de esa religiosidad. Fray Luis conocía bien ese texto (cfr. FLÓREZ MIGUEL, C.: «El Sueño de Escipión y la astronomía en la obra poética de fray Luis de León", en La Ciudad de Dios, CCXIV [2001] págs. 347-369). Se habla también, del "mito de Cristo», pensando en nuestro personaje. Así, por ejemplo, J.L. Abellán. Pero los mitos son fenómenos de cultura que suponen un referente «natural", del que, al sentir de fray Luis, habría que entenderlos "como nacidos". Su Cristo no podría ser ese derivado mítico, sino su primordial fuente (ver ABELLÁN, J.L.: Historia crítica del pensamiento español. II. Edad de oro (siglo XVI), Espasa-Calpe, S.A., Madrid, 1986, pág. 242). En el omnívoro lector que es Gustavo Bueno no sorprende encontrar que conoce los Nombres de Cristo; fijándose en el capítulo "Pimpollo", ve ahí la traza de un pensamiento en el que «todavía se moverá Hegel», el Hegel que 
"pone la verdad del cristianismo en la enseñanza de que el Hombre es Dios». Hombre escrito con mayúscula, que ahorra toda memoria previa de la verdad cristiana: la enseñanza de un Dios-hombre (BUENO, G.: El animal divino. Ensayo de una filosofía materialista de la religión. Pentalfa Ediciones, Oviedo, 1996, págs. 284-291 y pág. 44). Si pasamos a otro de sus libros, la asociación se hace con Zubiri y K. Rahner, subrayando el factor genético emergente y problematizando cualquier presencia preveniente o sobre-veniente, con lo que la conexión gnóstica (cfr. Nota 34) estará servida (BUENO, G.: Cuestiones cuodlibetales sobre Dios y la religión, Mondadori España, S.A., Madrid 1989, págs. 196-198). En ese mismo libro reduce a "proceso cósmico de crecimiento" todo lo que puede decirse respecto a la doctrina del capítulo "Pimpollo" de los Nombres (p. 57). Por lo demás, la doctrina de una "redención cósmica», abarcante de la creación entera, tuvo importantes defensores, ya desde la antigüedad cristiana, especialmente entre los Padres griegos (cfr. ARMSTRONG, A. H.: St. Augustine and Christian Platonism, Villanova University Press, 1967, págs. 17-24, 53 ss.).

29 Ver los capítulos II y IV de La perfecta casada.

30 Véase la contraposición que establece entre "poner ley" y "tener ley" (positiva/natural). "...Dar Ley puede acontecer en dos diferentes maneras. Una es la ordinaria y usada que vemos, que consiste en decir y señalar a los hombres lo que les conviene hacer o no hacer, escribiendo con pública autoridad mandamientos y ordenaciones de ello y pregonándolas públicamente. Otra es que consiste, no tanto en aviso como en inclinación; que se hace, no diciendo ni mandando lo bueno, sino imprimiendo deseo y gusto de ello. Porque el tener uno inclinación y prontitud para alguna otra cosa que le conviene, es ley suya de aquel que está en aquella manera inclinado, y así la llama la filosofía..." (NC, "Príncipe de la paz", pág. 613). Trasladada esa distinción al modo de gobernar, será igualmente de dos suertes. "Porque, como dice Platón, no es la mejor gobernación la de leyes escritas, porque son unas y no se mudan, y los casos particulares son muchos y que se varían, según las circunstancias por horas. Y así acaece no ser justo en este caso lo que en común se estableció con justicia; y el tratar con sola la ley escrita es como tratar con un hombre cabezudo por una parte y que no admite razón, y por otra poderoso para hacer lo que dice, que es trabajoso y fuerte caso. La perfecta gobernación es de ley viva, que entienda siempre lo mejor, y que quiere siempre aquello bueno que entiende» (NC, «Pastor», pág. 457).

31 «Y cuando suben, como dicen, el agua por una torre, entonces se tienen por la misma prudencia y por el dechado de toda la buena gobernación...» (NC, "Brazo de Dios», p. 545). Alusión al ingenio de Juanelo para elevar el agua del Tajo a la ciudad de Toledo. Con ironía parecida hace la crítica de otras empresas acometidas por los poderosos, entre ellas, por ejemplo, la de la construcción del Monasterio de El Escorial (cfr. Exp. Del libro de Job, en Obras, pág. 1023). Ese era el genio de fray Luis, compartido en la época por muchos hombres doctos. Recuérdese la negativa de aquella comisión de teólogos y hombres de letras a aprobar el proyecto de navegabilidad del Tajo sobre lo que el Rey Felipe II les pidió parecer.

32 Para la descripción de ese cambio de mentalidad en los siglos medios, ver CHENU, M.D.: La théologie au douzième siècle, Vrin, París, 1957, pág. 323 ss.; GREGORY, T.: Mundana Sapientia. Forme de Conoscenza nella cultura medievale, Edizioni di Storia e Letteratura, Roma, 1982, cap. 2: "Filosofia e teologia nella crisi del XIII secolo", pág. 61 ss.

33 Poesías, "Noche serena», en Obras Completas, 1471-1472. 


\section{Artes y ciencias en la formación de Fray Luis de León...}

34 Recogiendo cabos. La fraseología "genética», aplicada a Cristo, que ha ido apareciendo en el desarrollo habrá traído al recuerdo del lector el nombre de Teilhard de Chardin. No voy a discutir sobre su obra. Sólo indicar que ciertos críticos la han puesto en relación con el gnosticismo. A esa misma luz se han visto las metafísicas idealistas germanas del siglo XIX, con sus derivaciones posteriores, incluidas las materialistas. Se producen tras el final del principio-lógos suplantado por el principio-acción. Ahora bien, lo que caracteriza a todo gnosticismo, al menos en su forma antigua clásica, fue la dificultad que tenían para arreglárselas con la obra creadora del mundo. Ello supuesto, era inevitable que se movieran en una radical ambigüedad; radical, por afectar a la inidentificación de lo originario o principiativo. La consecuencia era la de tener que operar con un proceso emergente, sin presencia alguna directora en él; proceso que sería la nariz de cera que podría hacerse virar en cualquier dirección. ¡Para mundo abigarrado de filosofías, los gnosticismos! Que hay una vena en el pensamiento de fray Luis que induciría a interpretarle en esa dirección, ya los hemos advertido. Sería ésta ocasión oportuna para recordar su secreta, y no tan secreta, estima de la cábala y de otros esoterismos. Pero él mismo dice que, si no condenaba esas cosas, no las seguía. Sabemos también qué era lo que en última instancia sí seguía: la confesión de la creación del mundo por Dios y del Verbo-Logos divino encarnado, dogmas religiosos incasables con cualquier forma de gnosticismo. Metodológicamente puede ser práctico interesarse en primer lugar por el proceso deificador del hombre, pero lo ontológicamente primero es el humanizarse de Dios: In principio erat Verbum... Et Verbum caro factum est. Fray Luis explicó en su cátedra el tratado De creatione (Opera, VII); se interesó especialmente por el De Incarnatione (Opera, IV); para esta última doctrina, ver las dos primeras de sus Quaestiones variae, cuyos títulos no pueden ser más inequívocos: «I: Utrum probari possit contra Judaeos ex iis libris quos illi admitunt, et Christum venisse et eum fuisse Dominum Iesum». «II: Utrum Christus satis ostenderit se esse verum Deum» (Fray Luis de LEON: Quaestiones Variae (Opera, VIII), ed. por José Rodríguez Díez, Ediciones Escurialenses, Real Monasterio de El Escorial, 1992, págs. 9-51).

35 Ernst Bloch, con su "ateísmo en el cristianismo» formuló su cuasi-religión aventurera partiendo de supuestos análogos a los de Marcuse. Contando con Marx, sin excluir a Freud, y por trasfondo Hegel, nos ofrece una cuasi-cristogénesis en curso hacia el "sábado» de universal consumación, olvidando o silenciando la dimensión cristo-lógica. Consumación escatológica, sin memoria de protología alguna en los orígenes. Todo lo rige el principio esperanza, con olvido del principio fe. Lo que dice, en lenguaje tomado de la teología, es lo mismo que decía Marcuse en lenguaje derivado de las ciencias humanas (psicoanálisis de Freud, socio-historia marxista), resolviendo el principio de realidad (fe) en el principio del placer (esperanza). La dinámica resolutoria es similar y procede paralelamente en los dos casos. (Ver, para E. Bloch, Atheismus im Christentum, Frankfurt, 1968; para H. Marcuse, Eros and Civilization. A philosophical Inquiry into Freud, Boston, 1966.) Examinadas estas «ideaciones" a la luz de la historia encontraríamos en ellas las que serían (siguiendo con la frasis que venimos utilizando) cristologías incompletas, dotadas de una virtualidad mágica, en cuanto prometedoras de fines para los que no se ofrece pre-visión justificadora alguna. Cristología completa, aunque en la inmanencia (teología resuelta en filosofía), la última en ese terreno, y pensada a lo grande, es la que contiene el conocido axioma de Hegel: «lo que es racional es real y lo que es real es racional («Prefacio» a Fundamentos de la Filosofía del Derecho); Dios se realiza y es divinizada la realidad. Esto es lo 
que puede y a eso es a lo que aspira la Filosofía, como sucedía en su propio eón con la Teología. Aquellos otros intentos, los de los Marcuses y Bloches (incluidos los teólogos que ofician liturgias religiosas consonantes con esas profanas) son figuraciones en lo relativo, sin otro alcance que el de sus particulares filosofías. Fray Luis diría de esos particularismos que pueden rendir cierto provecho, pero que, olvidados del que es su origen genuino, su verdadero radical, «no bastan» y, dejadas a sí mismas, serán perniciosas (NC, «Príncipe de la paz», págs. 607-611). (Ver la observación hecha en la nota 25 ). 